\title{
Myth of Boki Sea: An Observation of Banggai Matriarchal Cultural Values
}

\author{
NURIYATI SAMATAN \\ Gunadarma University, Jakarta \\ FATHARANY BERKAH ABDUL BARRY \\ Tompotika University, Luwuk-Banggai
}

\begin{abstract}
This research analyzed the myth of "Boki Sea", folklore from Banggai Islands using the cultural anthropology approach through the analysis method of Levi-Strauss' structuralism to analyze the meanings in the myth. Data processing steps are ranging from reading text, decapitation of text into several chapters, determining the ceritheme, compiling the ceritheme into the relations of syntagmatic and pragmatic. The result of this study showed that Boki Sea is a myth created by Banggai people in looking at the facts through four levels: geographic, techno-economic, sociology, and cosmology. In geographic level, the origin of Boki Sea from Tano Kinombol (clay) formed by Temenenno; the place where Boki sea lives known as Tano Tuu; Boki Sea's residence, Sandung is lined with Sea Flowers or 'bunga pukul empat' (Mirrabilis Jalapa). The techno-economic level includes Boki Sea's wealth, the inheritance and the works of the four children of Boki Sea. In the sociological level, the matriarchal cultural values are found: worshiping to the Goddess or holy mother who is an embodiment of Mother Nature; Boki Sea managed the distribution of the inheritance; decision making is democratical; never differentiate the children based on gender. In cosmological level, the worship to the Pilogot Boki Sea in the ritual of Bapilogotan as 'the mother of life (Boki Tubuan); the worship to the Pilogot Sangkap, the children of Boki Sea, as believed as the four life symbols (pilogot sangkap). namely The Goddess of Sweet Potato Garden, God of Hunting, God of Catching Fish and God of Bees and Cuscus.
\end{abstract}

Keywords: Myth, Boki Sea, Banggai culture, communication studies, matriarchal cultural values.

\section{INTRODUCTION}

Myth is not something peculiar in human life. The term myth was first introduced by Plato (Menezes, 2017, 2019; Agrati, 2017; Tillotson \& Martin, 2015). The existence of myth is already believed in the history of mankind (Martins, 2012; Abel, 2011), although the stories refer to the things that are often considered absurd, strange and difficult to understand in everyday life (Sarma, 2014; Abel, 2011). On the other hand, myth represents the source of truth and a mean of justification in human life (Sailors, 2007; Tofighian, 2018), becomes the source of forming the national identity (Samuels, 2007; Michael, 2010; Aktar, Kızılyürek, \& Özkırımlı, 2010), and a tool to legitimize the regime (Stugu, 2003; Anderl, 2016). Myth is not only seen as an old form of literature, but also used to study culture and custom in the past (Ogbujah, 2014; Scarpaci, Coupey, \& Reed, 2018), and also part of the structure of science in the past (Farmer, 2018; Masse, Barber, Piccardi \& Barber, 2007). Quoting from William Righter (in Sterenberg, 2013): '[M]yth' has become a kind of intellectual shorthand which has gained acceptance as standing for an elusive, almost unanalysable amalgam of beliefs, attitudes, and feelings. The very unapproachability of the content of myth has created the utility of the term and guaranteed its 
widespread usefulness'. In broader explanation, myth can refer to traditional stories with the objects of the universe (Abel, 2011), topography, the state of the world with its inhabitants, as well as the descriptions of mythological creatures. In another study, myth becomes the foundation for the development of science (Masse, Barber, Piccardi \& Barber, 2007; Shalaeva, 2015).

Myth can emerge as exaggerated historical events, as allegories or personifications for natural phenomena, or as an explanation of rituals. They are spread to convey the religious or ideal experiences, to create specific characters and as a teaching material and identity (WongMingJi, Kessler, Khilji, \& Gopalakrishnan, 2014; Wesner, 2018) in a community. In society where myth is spread, it is usually considered as a story that happened in ancient times (Bascom 1984; Eliade 1963; Pettazzoni 1984). In reality, many people have two categories of traditional stories, namely "true story" or myth, and "fairy tales" or fables (Eliade, 1963; Pettazzoni, 1984; Burton \& Sun, 2015). Generally, the myth of creation takes place in the early period of the world (Bascom, 1984), and explains how the world acquires its present form, tradition, institution and established taboo (Dundes, 1984). In Indonesia, myth usually tells about the occurrence of the universe; the composition of the Gods; the first man; world of Gods; and the occurrence of staple foods, which the stories are presented through dances, songs, puppets, (Purwanto, 2001; Downes, 2017) and many others. The dialectic of myth has further stimulated the writer's curiosity to analyze the myth of Boki Sea by using the theoretical framework of Levi-Strauss.

\section{LITERATURE REVIEW}

\section{a. $\quad$ Myth in Communication Studies}

Myth is a Greek term "mythos" literarily meaning is a story or something that people say and in a broader meaning is a statement (Wachhaus, 2018; Meissner, 2017; Teo, 2014). From the opinion of Folklorist, "a myth is a sacred story explaining how the world and mankind are formed as it is today, a story that outlines the fundamental views of a culture by explaining the aspects of natural world and describing the psychological and social practices and the ideal view of society" (Luoch, 2016). In broader understanding, myth can refer to traditional story (Goetze, 2016), or in everyday conversation is considered as a misconception in a society or an imaginary entity.

Myth is closely related to legend and folklore (Doménech, Selva, Abad, \& Sabán, 2019). Myth, legend, and folklore are traditional stories in different type. Unlike myth, folklore can take place anytime and anywhere and it should not be considered real or sacred by people who preserve it. Legend, as like myth, is a story which traditionally considered as a story that happened, set in recent times, when the world was formed as it is today. Legend usually tells about an ordinary people as the main characters, while myth focuses on superhuman figure.

Traditional stories consist of myth, legend, and folklore. But some divide traditional stories into two, namely (1) directly referring folklore, and (2) combining myth and legend, even though myth and folklore are not entirely different. A story can be considered real (and become a myth) in a society but considered as unreal (and become a folklore) in another society. When a myth loses its status as part of religious system, myth often has more distinctive nature of folklore, with the characters of previous Gods being retold as heroes, giants, and fairies. Related to the discovery of the existence of common myths between a cultural community and other cultural community in various places, it is not caused by diffusion (spread) but due to the findings 
that stand alone. Those myths can be similar to each other, because as Carl Jung stated as a shared awareness that exists in every human being inherited biologically (Rafiek, 2010; Berger, 2013).

Myth is also equivalent with the word 'mythology' in English which means a study of myth or the content of myth. Mythology or myth is a collection of traditional stories that are usually told hereditarily from generation to generation in a nation or a tribe (Wadiji, 2011), and systematize it into a structure that tells all the myths in all versions relating to the culture surrounding and the various responses of the people about the myth (Kurzweil, 2010). Audifax, in his book entitled Mite Harry Potter: Psikosemiotika dan Misteri Simbol di Balik Kisah Harry Potter, explains Myth as follows:

Myth means stories from the past. Myth explains the essence of life and the world; or expresses the existence of cultural moral values in human life. Myth gives attention to the forces that control human life and the relationship between these forces and human existence. Although myth often has religious values in its form and function, myth is believed to be the earliest forms of history, science, or philosophy (Audifax, 2005).

Audifax's opinion is certainly relevant because before philosophy emerged long ago, Greek people had known myths (Schmukler, 2018; Sailor, 2007). These myths are the answers to the questions about riddles o mysteries about the universe and life that were experienced directly by Greek people at that time. These questions include the origin of humans (Abidin, 2011).

Myth is indeed better known to tell the stories from the past, which generally contains the interpretation of the universe and the existence of the creatures in it. The emergence of a myth can be a record of a historical event or an explanation of a ritual. One of the researchers of the myth is Claude Levi Strauss with his myth theory.

In communication, myth is a system that gives messages related to old rules, ideas, memories, or believed decisions (Berger, 2013). Therefore, myth is not a thing or a concept, but a symbol in a discourse (Barthes, 1981; Kasanova \& Widjayanti, 2018). A symbol in a myth is not always a text, but can be a film, certain objects, picture and so on. Myth is not a thing but can be symbolized by things (Hasanuddin, 1998).

The communication process that takes place in sending messages, especially in studying myth, can be described in the model of Schramm (1955) adapted by Blythe (2009). 


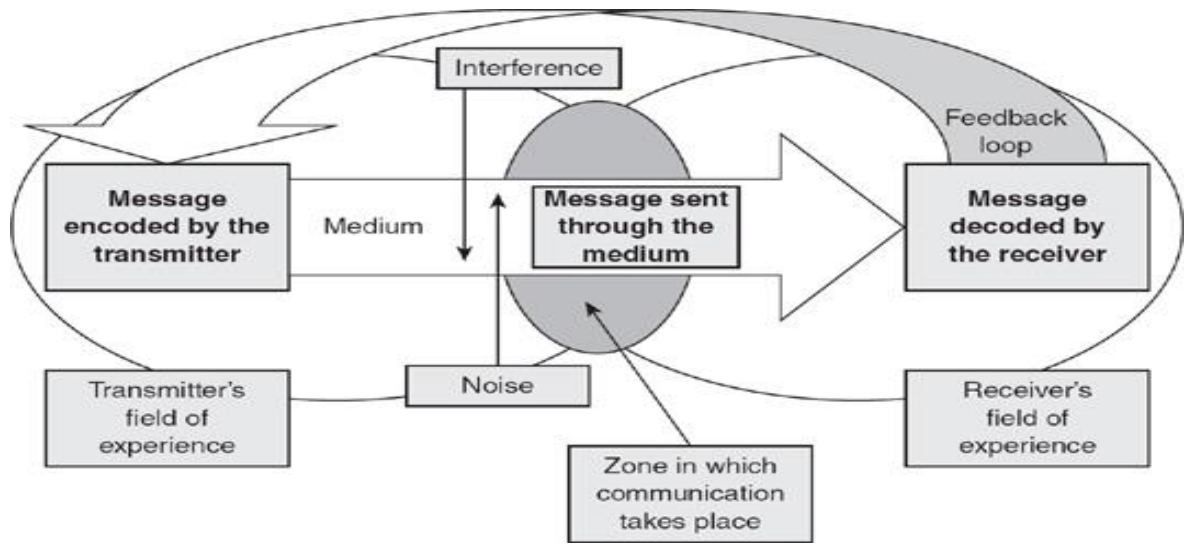

Figure 1. Comunication types Adapted from Schramm, 1955 (in Blythe, 2009)

Myth in the communication studies is 'messages' sent by old people, passed down from generation to generation through the encoding process, and uses he folklore as a 'medium'. The messages then received by the next generation. The sender and the recipient will be influenced by their respective experience. Experiences, background similarities (culture and language) will increase the similarity in understanding the messages equally. This interface will influence the level of common understanding and perception of myth from generation to generation. Noise can occur in the process of transmitting messages (Velentzas \& Broni 2017; Zhao, Zhu, Wang, Braut, Tang \& Cu, 2017), causing messages cannot be delivered as a whole, or changes in message's interpretation, that caused by experience, education, and socio-cultural changes.

\section{b. Structural Theory and Method of Levi Strauss}

Levi Strauss' structural theory Strauss (in Badcock, 1975; Jenkins, 1979; Dissard, 2014) is a theory that studies the myth (Scubla, 2017) occurs in a society (Torre, 2018), where there is a social phenomenon that is internally linked and regulated according to some unconscious patterns. Internal connections and patterns are structures and revealing these structures is the object of Levi Strauss's study. In general, a structure is intact, transformational, and selfregulatory. Structuralism is a methodology that emphasizes the structure rather than connection and substance. It states that a thing always comes out only as an element of a sign in a system.

According to Levi Strauss (in Kaplan \& Albert, 1999, p.240) the analysis of myth must be done likes an analysis of language. The elements of myth such as the elements of language do not contain any meaning. The meanings only arise when those meanings form a structure. Myth contains coded messages. While the structures of myth itself are dialectical which means the certain opposition and contradictions are displayed, male $><$ female, endogamy $><$ exogamy, brother $><$ sister, earth $><$ sky, and so on - then there is a kind of mediation or solution. Seeing from the relations and the functions, myth helps to describe four particular contradictions in life and then solves those contradictions (Kaplan \& Albert, 1999).

A cultural researcher, according to Strauss (in Clarke, 1978), besides generalizing the concept, he also studies the structures behind the human ideas, such as linguist who studies the structure of language (Doja, 2008), searching for a cultural phenomenon. It is based on the assumption that the actual reality is behind the empirical reality because the actual reality cannot 
be sensually grasped. There is a structure behind the empirical reality. It is realized that the community activities are seen as the empirical reality, but unwittingly that the community in their activities are limited by certain rules, which govern the activities. Levi Strauss called these rules as structures, which are at the cognitive level or ways of human thinking that considered fundamental and universal.

The understanding of the rules is based on the understanding of the language carried out by the linguist. Language is a symbolic communication code in the form of a set of symbols and a set of rules (grammar) to create a message (Cremers, 1997). Saussure (in Kridalaksana, 1998) stated that the basic unit of language is a sign consisting of two inseparable components; they are 'signifiant and signifie' or 'signifier and signified'. Signifier is the sound or acoustic component that signifies while the signified is the mental or conceptual component of the signified. If the signifiant is the material aspect of language then signifie is the understanding that arises in the mind of the speaker or listener when the signifiant is spoken.

One of the important principles in structural analysis is seeing things in a broader context that is the context of syntagmatic and paradigmatic relations, one of the Saussure's theories that widely used in literary studies. It was followed by Roland Barthes and Tzvetan Todorov, who classify the two concepts into syntactic and semantic aspects. In a discourse, words are interconnected and continuous, by the nature of language linearity, and it is not possible to recite two elements at once. On the other hand, outside the discourse, words that have similarities are associated with memory and become part of the reality of each individual in forming langue. The linear relationship is called syntagmatic relations, while the associative relationship is called paradigmatic relation. Both relations are often applied to analyzing poetry and fiction (Nurgiyantoro, 1993).

The syntagmatic relation is used to examine the structure of the work by emphasizing the order of the units of meaning that being analyzed. Syntagmatic relation, according to Todorov (Nurgiyantoro, 1993) is linear, configurative and constructive in terms of form or arrangement. In fiction, the relationship can be in the form of relations between words, events, or characters. Then how is an event followed by other events that have causality? How do the words relate to full meaning? And how do the characters form antithesis and gradation? To examine the structural linearity (to complete the structure of the text), according to Barthes (in Nurgiyantoro, 1993; Ritonga, Nugroho \& Handoko, 2019), the first thing to do is determining the units of a story (and their functions) by building the criteria for meaning.

Every unit of a story can consist of a number of sequences (units of meaning). In the study, each unit and sequence is given a symbol. According to Barthes (in Nurgiyantoro, 1993; Ritonga, Nugroho \& Handoko, 2019), the unit of the story has two functions, which are the main function and the catalyst. The unit of the story that has the main function is to determine the plot, while the unit of the story that has a catalyst function functions to connect those main functions. Todorov $(1985$, p. 41) suggests that the sequencing of the story units may be done in a temporal and logical order, chronologically or casually.

Paradigmatic relation, on the other hand, is the relationship of meaning and symbolism, associative context, meaning linkages, between the elements that exist and do not exist. It is used to analyze, for example, a certain signifiant that refers to certain signify, a certain event that is reminiscent of another event, symbolizing certain ideas or describing the mental state of a 
character (Todorov, 1985). Therefore the paradigmatic studies can be the study of a character (with all aspects), atmosphere, ideas, and many others. The basis of this study is the connotation, the associations that arise in the reader's mind. The events that related in meaning-perhaps symbolizing the psychological state of a character, certain ideas, or because there is a casual relationship - linearly (syntagmatic) where they may be far apart so that such a relationship can also be called the relationship in absentia (paradigmatic). For example, a number of events (units of the story) are placed at the beginning of the text, but logically they are related (at least can be associated) with other events, which are placed at the end of the text. In C. Levi Strauss's structural theory, these elements of unity consist of four paradigmatic levels, namely: 1) geographical level; 2) techno-economic level; 3) sociological level; and the cosmological level (Ahimsa-Putra, 2001). Those levels form signs. The signs are used as needed to convey the messages. Those four levels are essentially related to the study of the aspects of time (Nurgiyantoro, 1993). Todorov (1985) stated that the time problems are part of the verbal aspects of the period. Time, in a fictional text, consists of discourses that describe the story is linear, while time in the world is described as logical and associative.

\section{RESEARCH DESIGN}

This research is a Cultural Anthropology research using a descriptive-analytic method approach (Samatan, 2017), with data analysis technique adjusted to the application of the structural theory of Levi Strauss in analyzing the Indian myth entitled "The Story of Asdiwal" (McLaren, 1990) which had been applied by Ahimsa-Putra in his research in analyzing myth "Pitoto si Muhamma" from Bajo tribe (Ahimsa-Putra, 2001). Referring to the form of the analysis, then the Boki Sea story is sorted into several meaningful episodes. The selection of the criteria is based on the description containing the events that occurred. The intention is to get the parts that are called mytheme in the story. Ahimsa called it ceritheme. Ceritheme can be found in a sentence that contains the relation between the elements in the story.

Furthermore, after the ceritheme is obtained, the focus of the observation is directed at finding the smallest contuition unity, which is the relation in the form of short decision (subjectpredicate). This relation is numbered so that it is bound into a file that combines the various subrelations and classifies them all based on the same theme as related relations files. Each related file is placed in a vertical row. Several vertical lines will show the specific structural meaning of the myth. After the ceritheme is arranged diachronically in a syntagmatic and paradigmatic line as it is applied in language. This method is used to obtain the meaning of an element that depends on the syntagmatic and paradigmatic relations. Onwards, the ceritheme that contains the meaningful and unequal relations will be found. The interpretation of the meaning in the story of Boki Sea will depend on the overall relations of inter-ceritheme that can be found.

\section{Social Culture of Banggai People}

\section{RESULT AND ANALYSIS}

Banggai people who live on the mainland of Banggai (Banggai Regency located on Eastern Sulawesi Island) and on the offshore of Banggai (Banggai Regency located on Peling Island and Banggai Laut Regency on Banggai Island, Labobo, Bangkurung, and Bokan) realize that living well is living together in a harmony with philosophical values frame 'TuU-Tu' means integrity and 'Montolutusan' which means brotherhood or solidarity. 
Living in a society in unity and a strong brotherhood atmosphere is the essence of the life of the Banggai people; therefore all the life activities are mobilized for the sake of building and creating a better life together. The two value systems that are ideologically become the life principle of Banggai people. 'TuU-Tu' which means true or right is the life philosophy of Banggai people and becomes the moral guidelines in behaves both vertically and horizontally. While 'Montolutusan' is a life principle of Banggai people that teaches the meaning of the importance of brotherhood.

According to Mondika (2008), the values of 'Tuu-Tu' still can be found in the elderly of Banggai people where their characters: "When they speak, they speak softly, not too loud and they prefer to listen a lot than to speak. They do not like to show themselves or even feel great about themselves. They like to relent and easy to adapt to everyone. They are newer jealous of other people's success. Their appearances are simple and not arrogant, love their families, easy to thank and not ambitious." While 'Montolutusan' (Abdul Barry, 2016), is a living cultural doctrine, that teaches the life values and principles of Banggai people; "as the fellow brothers, a human should encourage, support, and look after each other in kindness. Humans should not oppress each other, deceive, and envy each other, should not kill, revenge, and be the jealousy of each other. Humans should humanize each other in kindness.

The myth of the Boki Sea is a symbol of the power of Banggai women because in their behaviors and actions there are the leadership and wisdom values with 'Tuu-tu' (integrity) and 'Montolusan' (fairness).

\section{The Myth of Boki Sea in Banggai People}

The majority of Banggai people believe that their ancestors came from "Tano Tu" where the Temeneno (the ruler of the universe) took a lump of clay in a place called "Tano Kinombol" then made into a pair of humans, the man (Langkai) descended in Tokolong, while the woman (Boki) is descended in Lipubasal. In the story of the narrative, we find more about the story of Boki Sea, and almost there is no narrative about the Langkai Sea. It is because of the belief system of the Seasea -the old Banggai tribe that glorified the figure of a mother (woman) as the source (intermediary) of the human existence in this world or can be called Boktibuan which means the mother of life. According to Dr. Aser Yalindua, Boki Sea lives in TanoTuu where the topography is flat (mesea,) the location now is called "Lipu Tanga" in the Osan area with her four children (one daughter and three sons). The daughter's name is Sulape, and the son's names are Tompudau, Sama, and Samalangan. Her house (sandung) is lined with Sea Flowers or 'bunga pukul empat' (Mirrabilis Jalapa) which is a time-guided flower. The four children and this kind of flower (Mirrabilis Jalapa) are the origins of the myth of number ' 4 ' (four) which has significant meaning for Banggai people (Abdul Barry, 2016).

It is said that when the four children (a daughter and three sons) have grown up, Boki Sea divided the heirloom land to her four children as follows: (1) Sulape, the eldest child, a daughter, still lives with her mother in West Peling with the inherited land in Buko region and part of Bulagi region. She was also given a legacy in the forms of agricultural tools and skills. (2) Tompudao, the second child, was given the inheritances of a chair and a weapon (Pandong) with very large land in the eastern part of Seasea which is part of Bulagi region, the whole area of Liang, Totikum, Tinangkung, Banggai, Labobo, Bangkurung and Bokan. (3) Sama, the third child, he was not given 
the inheritance in the form of land and was only given a bamboo woven then used as fishing gear (Polon), but he was given the freedom to control the sea which became his inheritance and he can live anywhere in that part of the inheritance. And (4) Samalangan the youngest child, was given an umbrella and candied honey as the inheritances. He was asked to go abroad to faraway place across the ocean. Related to this youngest child, there are two versions of the story about the place where Samalangan went. The first version mentions that the youngest son of Boki Sea crossed over Tanah Besar (Banggai Darat) and descended the Loon tribe (BalantakAndio), Loinang tribe (Saluan) and kings in Banggai Darat. But another version says that the youngest went to Java, became a King in one of the kingdoms in Java and had descendants namely Raden Cokro (Adi Soko). Later came to Banggai and became the first king of Bangai in the modern era of Banggai kingdom (Abdul Barry, 2016).

Then he is the pioneer, the descendant of Boki Sea, who later descended the civilization of Tokolong Kingdom (Se-sea). Tokolong Kingdom is an ancient kingdom in the land of Banggai which the center of the kingdom is located in Palabatu, now is known as South Bulagi District, Banggai Islands Regency, until the generation of Kusaoli aka MianTuu Fuadin, the Leader of Seasea who has title Lipu Adino and now had converted to Islam, until the dynasty of Olu (the kings of Old Bangai) which was passed down by Doduung, a descendant from Tompudau (Abdul Barry, 2016).

In the practice of the religious life in the old time, Banggai people believed in supernatural and mystical powers through the symbol of Pilogot (Gods) and Balakat (the worshiped sacred place), where the rituals were performed in Kusali (place of worship). In this tradition, there are many Pilogot (Gods and Goddess), but the most important $s$ the worship of Boki Sea who generally the mother of life (Boki Tuboan) and Pilogot Sangkap who is the son of Boki Sea. Boki $S e a$ is Boki Sea who is believed as the ancestor of the Banggai people. The sacredness of the Boki Sea is inseparable from the beliefs of the old Banggai tribe who glorified the figure of mother (woman) as the source (intermediary) of the human existence in this world. "The meaning role of a woman or a mother in the local wisdom of Banggai people is very important and sacred, that there are the principles kept by Banggai's children namely "Loi Monodok Tinotoanggon Tama Sakat Lunggon, Tadukai Tinotoanggon Idan kai Tina, which means It is better to cursed or sworn by a father rather than being sworn once by a mother." Because of that wisdom, one of the characteristics of the true Banggai people is to respect their mother and to respect the rights of women (Abdul Barry 2016).

This is the reason that Boki Sea was later symbolized as Boki Tuboan (Mother of Life) in Pilogot's belief including her four children who were also considered as four symbols of life (Pilogot Sangkap), they are: Goddess of Sweet Potato Garden (Sulape); God of Hunting (Tompudau); God of Catching Fish (Sama); and God of Bees and Cuscus (Samalangan). They must also be respected by humans so that the balance of human life and nature is maintained (Kruyt, 1932).

\section{Structure Analysis of the Myth of Boki Sea in Banggai People}

From the sequential reading of the story about the myth of the Boki Sea, it can be split into several significant episodes. There are nine cerithemes in the myth of Boki Sea, namely: 1) The origin and the incident process of Boki Sea; 2) The area where Boki sea lives; 3) The residence of Boki Sea; 4) The power of Boki Sea; 5) The wealth of Boki Sea; 6) Distribution of inheritance 
(budel) including the works of the four of Boki Sea's children; 7) The central role of Boki Sea as devisor of inheritance to the four children; 8) The worship to the Pilogot Boki Sea in the ritual of Bapilogotan; 9) The worship to Pilogot Sangkap who are the children of Boki Sea (Abdul Barry, 2016).

The cerithemes are found in words, phrases, sentences, paragraph section, or paragraph that indicate certain meaning that can be positioned in certain relationship with other ceritheme. Each ceritheme has a sequence of relation concretely and functionally, therefore the ceritheme is arranged in the order in which they are told. The numbering process is done for each ceritheme that is understood simply as the core of the story. The nine cerithemes that had been found then were separated based on the distinguishing feature that determined, than placed based on the syntagmatic and paradigmatic rules as the classification used by Levi Strauss.

After reading the placement of the nine cerithemes in the syntagmatic and paradigmatic lines, in analyzing the result of this discussion, it is carried out by following the direction from the top to the bottom, showing the arranged data on the four levels. The first and the third levels contain the idea of dichotomy between the origin and supernatural (leadership ability). The first level contains the idea of the origin, the process of events, and the environment condition where they live. The third level contains the power or leadership ability of a mother (woman) in carrying out the leadership function to her children. The second level contains matriarchal concept and the symbolism of the interactions of religious life with the universe.

The followings are the mythical structures of Boki Sea in the four levels of Levi Strauss, namely: (a) geographical level; (b) techno-economic level; (c) sociological level; and (d) cosmological level. According to Ahimsa (2001) the geographical level and the techno-economic level are found in the narrative of empirical reality, which is quite accurate and clear. The cosmological level has nothing to do with the reality, whereas the sociological level is in the form of interconnected images of real and imaginary institutions.

\section{a) Geographical Level}

Geographical level describes the natural form and circumstances that occur in the story, where the location of the occurrence of a story becomes the source of data at this level. From the research, there are three levels of the geographical level. First, the origin and the process event of Boki Sea originating from Tano Kinombol (clay) formed by Temeneno (the ruler of nature), a pair of humans, the man (Langkai) descended in Tokolong (Buko) while the woman (Boloki) is descended in Lipubasal (Bulagi). Second, the place where Boki Sea lived in TanoTuu, now is called "Lipu Tanga" where the topography is flat (mesea) at the top of the mountains in the Osan village, South Bulagi District, Banggai Islands Regency. Third, the residence of Boki Sea, Sandung' house is lined with Sea Flowers or 'bunga pukul empat' (Mirrabilis Jalapa) which is a time-guided flower.

\section{b) Techno-Economic Level}

Techno-economic level or economic level related to the economic situation that occurs in a story. The economic activities in the story can be observed through the livelihood and assets owned by the figures being told. In this research, there are two levels of the techno-economic level. First, the wealth of the Boki Sea in the form of a vast Banggai heirloom, the knowledge of 
farming and hunting, and objects such as chairs (throne), farming tools such as machete (bakoko), a weapon for hunting such as spears (pandong), fishing gear (Polon), umbrella (kokoa), candid honey and others. The second is the inheritance (budel) and the works of the four children of Boki Sea. Sulape is farming, mastering agriculture; Tompudau is hunting, ruling over the territories, inheriting properties of chair and weapon, vast lands which are the half area of Bulagi, all area of Liang, Totikum, Tinangkung, Banggai, Labobo, Bangkurung, and area of Bokan; Sama, a sailor, ruling and protecting the ocean, getting the inheritance of fishing gear (polon); and Samalangan, an explorer, inheriting an umbrella (a symbol of protection) and candied honey (symbol of joy).

\section{c) Sociological Level}

In the sociological level, the relationship between people is analyzed. It is due to the human character, which is a social creature. They cannot live without the help of others. In a society, there is a social status to show someone's power in that environment. This research finds two sociological levels. First, there is an element of matriarchal cultural values where the central role of Boki Sea (mother/woman) is described concretely. How this culture manages everything related to the distribution of the inheritance to her four children. 1) Sulape (the daughter), she lives with her mother in TanoTuu. She was given the skills of farming and the farming tool (bakoko);2) Tompudau (second son) given the inheritance of chain and weapon, as well as a very large inheritance of land that is part of the Bulagi region, the entire area of Liang Totikum, Tinangkung, Banggai, Labobo, Bangkurung, and Bokan; 3) Sama (the third son) given the skills of fishing and inheritance of the fishing gear (polon); 4) Samalangan (the youngest son) is a nomad (lausala). His inheritances are an umbrella (cocoa), a symbol of protection and candied honey, a symbol of joy. Second, the elements of matriarchal culture values of Boki Sea are confirmed through several "matriarchal cultural characteristics" namely: a) the decision making is democratic and involves all parties, women, men, old, and young. Everyone can express their opinion; b) worshiping a Goddess or a holy mother who is worshiped as the mother origin of e community which is an embodiment of Mother Nature; c) do not know the concept of children based on their sex. Therefore boys and girls are equally respected. Children are prospective individuals both male and female.

\section{d) Cosmological Level}

The cosmological level analyzes the characters in interacting with the Creator. The interaction with the Creator can be done in various ways. Two cosmological levels contained in this research. First, the worship of Pilogot Boki Sea in general in the ritual Bapilogotan as "the mother of life (BokiTuboan)", Boki Sea is believed to be the ancestor of the Banggai people. The sacredness of Boki Sea is inseparable from the beliefs of Banggai people of the past who glorified the figure of the mother as the source (intermediary) of human life that exists in this world. Second, the worship of Pilogot Sangkap, the children of Boki Sea is believed to be four symbols life (Pilogot Sangkap), namely: The Goddess of Sweet Potato Garden (Sulape), God of Hunting (Tompudau); God of Catching Fish (Sama); and God of Bees and Cuscus (Samalangan), where the four Pilogot Gods are believed to be the representations the 4 (four) main elements of the universe (macrocosms), namely water (Sama), Land (Sulape), Fire (Tomudau), and Wind (Samalangan). 


\section{CONCLUSION}

This research proves that myth functions as human reasoning tools in describing the world and surrounding and also interpreting the phenomena of the universe. From the myth of Boki Sea, Banggai people learned to understand their cultural values and provide legitimacy about what and how women should be positioned and play a role in the family and the community of Banggai. The presence of Boki Sea as Boki Tuboan (the mother of life or intermediary) of human existence in this world, with a central role as an educator and leader for her four children who later became Pilogot Sangkap (Four Gods) is an affirmation of the existence of a variable from the matrilineal system in the cultural life of the Banggai people in the past.

From the comprehensive analysis of the nine ceritheme in the story of Boki Sea and the structure of the myth of Boki Sea, using Levi Strauss's approach in analyzing myth, it is concluded that there is certain regularity in the myth of Boki Sea. The regularity is in the form of content structure or ideas of Boki Sea's myth that shows the mindset of the classical Banggai people who highly respect the figure of a woman. Despite the reality of the social life of the Banggai people nowadays draws the patriarchal kinship lines. The peculiarity of the Banggai Matriarchal values lies in the role of the mother figure as an educator and devisor of inheritance in a democratic family by not giving priority to the sexual status of her children.

\section{BIODATA}

Nuriyati Samatan is a lecturer in Communication Research and Communication Theory in Faculty of Communication Science, Gunadarma University, Jakarta. Her research interest and focus include Cultural Studies mainly the research about a woman and gender equality using the qualitative method and focus group discussion. Email: nuri@staff.gunadarma.ac.id / nuriyatisamatan@gmail.com

Fatharany Berkah Abdul Barry is a lecturer of Social Science and Politics Science in Faculty of Social and Politics Science, Tompotika University, Luwuk-Banggai, Indonesia. His research includes Social and Political Studies using the qualitative method. Email: abdulbarryfb@outlook.com 


\section{REFERENCES}

Abdul Barry, F. B. (2016). Kamimo banggai; ikhtiar dan konsepsi. Jakarta: YPAB Press.

Abel, C. F. (2011). Considering myth in public administration. International Journal of Organization Theory and Behavior, 14(2), 163-167.

Abidin, Z. (2011). Pengantar filsafat barat. Jakarta: Rajawali Pers.

Agrati, L.S. (2017). Plato's myth of the cave images. A didactic analysis of the mediation function. Proceedings 2017, 1, 1091. doi: 10.3390/proceedings1091091

Ahimsa-Putra, H. S. (2001). Strukturalisme Lévi-Strauss: Mitos dan karya sastra. Yogyakarta: Galang Press.

Aktar, A., Kızılyürek, N., \& Özkırımlı, U. (Eds.). (2010). Nationalism in the troubled triangle. New York, US: Palgrave Macmillan.

Anderl, F. (2016). The myth of the local. The Review of International Organizations, 11(2) 197218. doi :10.1007/s11558-016-9248-x

Audifax. (2005). Mite Harry Potter psikosemiotika dan misteri simbol di balik kisah Harry Potter. Yogyakarta: Jalasutra.

Badcock, C. R. (1975). Lévi-Strauss: Structuralism and s ociological theory. London: Routledge Taylor \& Francis Group.

Barthes, R. (1981). Mithologies. New York: Granada Publising.

Bascom, W. (1984). The forms of folklore: Prose narratives. In A. I. Dundes (Ed.), Sacred narrative: Readings in the theory of myth. Berkeley: University of California Press.

Berger, A. A. (2013). Media, myth, and society (1st ed.). New York: Palgrave Macmillan.

Blythe, J. (2009). Key concepts in marketing. London: SAGE Publication, Ltd.

Burton, L., \& Sun, L. G. (2015). Introduction: The myths we live (and die) by. Special Issue: Cassandra's Curse: The Law and Foreseeable Future Disasters (Studies in Law, Politics, and Society, Vol. 68, pp. 1-13). Emerald Group Publishing. doi: 10.1108/S1059433720150000068001

Clarke, S. (1978). The origins of Levi-Strauss's structuralism. Socioloy, 12(3), 405-439. Thousand Oaks: Sage.

Cremers, A. (1997). Antara alam dan mitos: Memperkenalkan antropologi struktural Claude LeviStrauss. Ende NTT: Nusa Indah.

de la Torre, S. (2018). Madness and the sensitive anthropologist: Lévi-Strauss's new structuralism. In, Sex for structuralists. Cham: Palgrave Macmillan. doi: https://doi.org/10.1007/978-3-319-92895-1_3

Dissard, L. (2014). Lévi-Strauss, Claude. In L. Weiss, U. Z. Rizvi, \& W. Londono (Eds.), Encyclopedia of global archaeology: Political and social archaeology. Springer Press.

Doja, A. (2008). Claude Lévi-Strauss at his centennial: Toward a future anthropology. Theory, Culture \& Society, 25(7-8), 321-340.

Doménech, J. L. U., Selva, J. A. N., Abad, L. S., \& Sabán, M. (2019). Dialectical logic for mythical andmystical superstructural systems. Kybernetes, 48(8), 1653-1680.

Downes, M. (2017). Women writing wayang in post-reform Indonesia: A comparative study of fictional interventions in mythology and national history. In Chin G., \& Mohd Daud, K. (Eds.), The Southeast Asian woman writes back (Asia in transition, Vol. 6, pp. 107-127). Singapore: Springer. 
Dundes, A. (1984). Introduction; Sacred narrative: Readings in the theory of myth. Berkeley: University of California Press.

Eliade, M. (1963). Myth and reality. New York: Harper \& Row.

Farmer, D. J. (2018). Sub-administration: Ideologies, myths and metaphors. International Journal of Organization Theory \& Behavior, 21(3), 140-149.

Goetze, C. (2016). Bringing Claude Lévi-Strauss and Pierre Bourdieu together for a poststructuralist methodology to analyse myths. In B. Blieseman de Guevara (Ed.), Myth and narrative in international politics: Interpretive approaches to the study of IR (pp. 87-105). UK: Palgrave Macmillan.

Hasanuddin, W. S. (1998). Pengaruh mitos dalam karya sastra Indonesia Warna Lokal Minagkabau. Majalah Humanus. Padang: Lemlit IKIP.

Jenkis, A. (1979). The social theory of Claude Lévi-Strauss. London: The Macmillan Press Ltd.

Kaplan, D., \& Albert M. (1999). Teori budaya (Terj). Yogyakarta: Pustaka Pelajar.

Kasanova, R., \& Widjajanti, S. (2018). Mitos dan kontramitos dalam novel mantra penjinak ular karya kuntowijoyo. Deiksis - Jurnal Pendidikan Bahasa dan Sastra Indonesia, 5(2), 103113.

Kridalaksana, H. (1988). Pengantar linguistik umum. Yogyakarta: Gadjah Mada University Press. Kruyt, A. C. (1932). De Zwarter kunst in den banggai archipel en in Balantak. Netherlands: Brill.

Kurzweil, E. (2010). Jaringan kuasa strukturalisme dari Levi-Strauss sampai Foucault (The age of structuralisme from Levi-Strauss to Foucault, Terj. Nurhadi). Yogyakarta: Kreasi Wacana.

Luoch, T. O. (2016). The myth of language as a unifying factor conflict in monolingual Rwanda and Somalia. W. S. Nasong'o (Ed.), The roots of ethnic conflict in Africa from grievance to violence. UK: Palgrave Macmillan. Retrieved from http://erepo.usiu.ac.ke/11732/2437

Martins, N. U. (2012). The position of oral tradition (Myths, mythology and legends). 2012 International Conference on Humanity, History and Society IPEDR (Vol.34). Singapore: IACSIT Press.

Masduki, A. (2015). Mitos dan hiperrealitas komunikasi politik (Studi iklan pemilu Jusuf KallaWiranto versi humble dan mampu). INFORMASI Kajian IImu Komunikasi, 45(2), 125-139.

Masse, W. B., Barber, E. W., Piccardi, L., \& Barber, P. T. (2007). Exploring the nature of myth and its role in science. In Piccardi, L., \& Masse, W. B. (Eds.), Geological society: Myth and geology (Special Publications No. 273, pp. 9-28). London: The Geological Society.

McLaren, D. L. (1990). Structuralism and "the story of Asdiwal": A re-analysis of a Tsimshian Myth (Thesis Degree Master of Arts, School of Graduate Studies, McMaster University, Hamilton, Ontario).

Meissner, M. (2017). Mythical crisis perspectives. In Meissner, M. (Ed.), Narrating the global financial crisis urban imaginaries and the politics of myth. New York, US: Palgrave Macmillan.

Menezes, L. M. B. d. R., (2017). Arte, filosofia e governo: O desafio do filósofo governante na República de Platão (Tese de Doutorado em Filosofia, Instituto de Filosofia e Ciências Sociais, da Universidade Federal do Rio Janeiro). Retrieved from https://ppglm.files.wordpress.com/2018/03/tese-ppglm-ufrj-luiz-mauricio-rmenezes.pdf

Menezes, L. M. B. d. R., (2019). Myth in Plato's philosophy. Investigação Filosófica, 10(1), 7-13. 
Michael, M. N. (2010). History, myth and nationalism: The retrospective force of national roles within a myth-constructed past. In Aktar A., Kızılyürek N., \& Özkırımlı U. (Eds.), Nationalism in the troubled triangle: New perspectives on south-east Europe (pp. 149159). London: Palgrave Macmillan.

Meissner, M. (2017). Mythical crisis perspectives. In, Narrating the global financial crisis: Urban imaginaries and the politics of myth (Palgrave Studies in Globalization, Culture and Society book series (PSGCS), pp. 17-40). Cham: Palgrave Macmillan. doi: https://doi.org/10.1007/978-3-319-45411-5_2

Mondika, H. (2008). Banggai Darussalam, solusi di tengah krisis. Jakarta: LP2M.

Nurgiyantoro, B. (1993). Teori pengkajian fiksi. Yogyakarta: Gadjah Mada University Press.

Ogbujah, C. (2014). Exploring myths: A key to understanding Igbo cultural values. Conference at International Society for Universal Dialogue (ISUD) Tenth World Congress (Vol.10). Craiova, Romania.

Pettazzoni, R. (1984). The truth of myth. In A. Dundes (Ed.), Sacred narrative: Readings in the Theory of myth. Berkeley: University of California Press.

Poedjawijatna. (1994). Pembimbing ke arah alama filsafat. Jakarta: Renika Cipta.

Purwanto, B. (2001). Reality and myth in contemporary Indonesian history. Humaniora, XIII(2), 111-123.

Rafiek, M. (2010). Teori sastra: Kajian teori dan praktik. Bandung: Rafika Aditama.

Ritonga, R., Nugroho, E., \& Handoko, D. (2019). Struggle of meaning and the Jokowi myth in the 2018 asian games opening video. Jurnal Komunikasi: Malaysian Journal of Communication, 35(1), 137-155.

Sailors, C. L. (2007). The function of mythology and religion in ancient Greek society (Thesis Master of Arts in History, School of Graduate Studies, East Tennessee State University). Retrieved from https://dc.etsu.edu/cgi/viewcontent.cgi?article=3471\&context=etd

Samatan, N. (2017). Riset komunikasi 1. Jakarta: Penerbit Gunadarma.

Samuels, W. J. (2007). Notes on a faculty seminar series on myth, theology and society: Given by Robert T. Anderson, Michigan State University, fall term, 1974. Samuels, W. (Ed.), Further documents from the history of economic thought (Research in the History of Economic Thought and Methodology, Vol. 25, Part 3, pp. 257-284). Bingley: Emerald Group Publishing Limited. doi: 10.1016/S0743-4154(06)25030-2

Sarma, P. J. (2014). Historical myths or mythological history: A fresh approach to understand the history of assam. Space and Culture, India, 2(3), 62-73.

Scarpaci, J., Coupey, E., \& Reed, S. (2018), Artists as cultural icons: The icon myth transfer effect as a heuristic for cultural branding. Journal of Product \& Brand Management, 27(3), 320333. doi: 10.1108/JPBM-02-2017-1416

Schmukler, R. (2018). Myths as errors and inventions: The shadow of tradition in PA praxis. International Journal of Organization Theory \& Behavior, 21(3), 158-170.

Schramm, W. (1955). How communication works. In W. Schramm (Ed.), The process and effects of mass communication. Urbana: University of Illinois Press.

Scubla, L. (2017). Lévi-Strauss and Girard on mythology and ritual. In: Alison J., \& Palaver W. (Eds.), The Palgrave handbook of mimetic theory and religion (pp. 85-93). New York: Palgrave Macmillan. doi: 10.1057/978-1-137-53825-3_12 
Shalaeva, A. (2015). The scientific study of myth: Romantic account of symbolism and mythology (April 15, 2015). Higher School of Economics Research Paper No. WP BRP 100/HUM/2015. Retrieved from https://papers.ssrn.com/sol3/papers.cfm?abstract_id=2594796

Shalaeva, A. (2014). Symbolism and mythology of the ancients: An outline of Georg Friedrich Creuzer's argument. Higher School of Economics Research Paper No. WP BRP 80/HUM/2014 (December 14).

Sterenberg, M. (2013). Mythic thinking in twentieth-century Britain: Meaning for modernity. New York, US: Palgrave Macmillan.

Stugu, O. S. (2003). Myths, History and the construction of national identity. European Summer University Conference: The Misuse of History Strasbourg, July 2, 2013.

Teo, T. (Ed.). (2014). Encyclopedia of critical psychology. NY: Springer.

Tillotson, J. S., \& Martin, D. M. (2015). Myth - Mediated branding. Consumer Culture Theory Research in Consumer Behavior, 17, 198-221.

Todorov, T. (1985). Tata sastra (Terj.). Jakarta: Djambatan.

Tofighian, O. (2018). Myth and philosophy in platonic dialogues. UK: Palgrave Macmillan.

Velentzas, J., \& Broni, G. (2014). Communication cycle: Definition, process, models and examples. Proceedings of the 5th International Conference on Finance, Accounting and Law (ICFA '14). Istanbul, Turkey: 15-17 December 2014. Retrieved, Juny, 20, 2019, from http://www.wseas.org/main/books/2014/Istanbul/FINANCE.pdf

Wachhaus, A. (2018). Governance myths: A typology. International Journal of Organization Theory \& Behavior, 21(3), 211-223.

Wadiji. (2011). Akulturasi budaya Banjar di Banua Halat. Yogyakarta: Pustaka Book Publisher.

Wesner, S. (2018). The artist and the artistic myth. In, Artists' voices in cultural policy: New directions in cultural policy research (pp. 17-40). Cham: Palgrave Macmillan. doi: 10.1007/978-3-319-76057-5_2

Wong-MingJi, D. J., Kessler, E. H., Khilji, S. E., \& Gopalakrishnan, S. (2014). Cross-country perspective: Cross-cultural comparison of cultural mythologies and leadership patterns. South Asian Journal of Global Business Research, 3(1), 79-101.

Zhao, L., Zhu, B., Wang, J., Brauth, S. E., Tang, Y., \& Cu, J. (2018). A model for immune noise towards high-fidelity quantum secure communication. International Journal of Theoretical Physics, 58(3), 201-208. 